\title{
Complement C4a Measurement
}

National Cancer Institute

\section{Source}

National Cancer Institute. Complement C4a Measurement. NCI Thesaurus. Code C80178.

The determination of the amount of complement C4a present in a sample. 